\title{
Chloroquine: its effect on leucocyte auto- and heterophagocytosis
}

\author{
CAROLYN J. P. JONES AND MALCOLM I. V. JAYSON \\ From the Rheumatic Diseases Centre, University of Manchester, Hope Hospital, \\ Salford M6 $8 H D$
}

SUMMARY The effect of chloroquine on phagocytosis and leucocyte ultrastructure has been examined. Incubation of neutrophils in $50 \mu \mathrm{g} / \mathrm{ml}$ chloroquine for 15 minutes produced a significant inhibition of latex particle uptake. After 90 minutes both 50 and $5 \mu \mathrm{g} / \mathrm{ml}$ inhibited phagocytosis while 7 of 9 cases were also inhibited at $0.5 \mu \mathrm{g} / \mathrm{ml}$. However, after 4 hours $50 \mu \mathrm{g} / \mathrm{ml}$ chloroquine caused neutrophil granule vacuolation and a massive increase in autophagosomes in other cell types. Incubation in 5 to $0.05 \mu \mathrm{g} / \mathrm{ml}$, which includes therapeutic plasma levels, had no effect on neutrophil ultrastructure but produced a dose-related increase in the number of lymphocytes containing autophagosomes, reflecting altered lysosomal function. As the antimalarial effect of chloroquine is manifested by giant autophagosome formation in Plasmodium, a common antirheumatic and antimalarial mechanism of action is postulated.

Antimalarials have been used to treat connective tissue diseases since 1894, when Payne ${ }^{1}$ reported the beneficial effects of quinine in the treatment of lupus erythematosus. Various antimalarial drugs have subsequently been developed, of which those with a 4-aminoquinoline structure such as mepacrine, chloroquine, and hydroxychloroquine have been most successful in the treatment of rheumatic conditions. The efficacy of these compounds is reported to approach that of gold, penicillamine, and azothioprine. $^{2}$

Although its exact mode of action is not yet understood, chloroquine is reputed to exert antiinflammatory and immunosuppressive effects as well as the suppression of protein biosynthesis. ${ }^{2} \mathrm{We}$ have examined the in-vitro effect of chloroquine on the phagocytosis of latex particles by polymorphonuclear neutrophils, using a technique previously described. ${ }^{3}$ The bizarre alterations in cell ultrastructure following incubation in chloroquine prompted a detailed examination of the morphological changes occurring in leucocytes after exposure to varying concentrations of chloroquine, and the results have led us to propose a link between the antimalarial and antirheumatic modes of action of this drug.

Accepted for publication 20 May 1983.

Correspondence to Dr C. J. P. Jones, Pathology Department, University of Manchester, Manchester M13 9PT.

\section{Materials and methods}

\section{PHAG OCYT OS IS}

Leucocytes from the heparinised blood of healthy male volunteers were isolated by dextran sedimentation at $37^{\circ} \mathrm{C}$ for one hour. The resulting cell-rich supernatant was washed twice in Dulbecco's modification of Eagle's medium (DMEM) at $4^{\circ} \mathrm{C}$ and the concentration adjusted to $10^{7}$ cells per ml. Trypan blue exclusion indicated a viability of over $98 \%$. Chloroquine diphosphate (Sigma) was dissolved in $\operatorname{DMEM}(1 \mathrm{mg} / \mathrm{ml})$ and serial dilutions were made to $10^{-2} \mathrm{mg} / \mathrm{ml}\left(10^{-3} \mathrm{mg} / \mathrm{ml}\right.$ for morphological studies $)$. These were further diluted, and $1 \mathrm{ml}$ aliquots of the cell suspension were then mixed with an equal volume of chloroquine solution, or medium only, to give final concentrations of 50,5 , and $0.5 \mu \mathrm{g} / \mathrm{ml}$ chloroquine $\left(9.7 \times 10^{-5} \mathrm{M}\right.$ to $\left.9.7 \times 10^{-7} \mathrm{M}\right)$. Incubation was carried out at $37^{\circ} \mathrm{C}$ in $5 \% \mathrm{CO}_{2}$ in air for 90 minutes, after which vials were transferred to a shaking water bath $(160$ shakes/minute $)$ at $37^{\circ} \mathrm{C}$ and given $100 \mu \mathrm{l}$ of $0.81 \mu \mathrm{m}$ diameter latex particles (Difco) for exactly 10 minutes. Fixation, processing for electron microscopy, and analyses were carried out as previously described ${ }^{3}$ and grids were coded so that specimens were examined blind. This experiment was performed on 9 samples of blood.

In 8 experiments incubations were carried out for 15 minutes only, followed by a 10 -minute period of 
latex ingestion; cells were allowed to reach $37^{\circ} \mathrm{C}$ in the shaking water bath before the addition of chloroquine. Wilcoxon's matched pairs signed ranks test was used to compare counts of ingested particles in drug-treated and control populations. A phagocytic index was calculated as follows:

Particles in 100 control cells - particles in 100 test cells

Particles in 100 control cells

\section{MORPHOLOGICAL STUDIES}

The effect of $50 \mu \mathrm{g} / \mathrm{ml}$ chloroquine on the ultrastructure of normal leucocytes was examined at 1,2 , and 4 hours; cells exposed to $5,0.5$, and $0.05 \mu \mathrm{g} / \mathrm{ml}$ were fixed only after the full 4-hour period. Cells were isolated as above and incubated for the specified time at $37^{\circ} \mathrm{C}$ in $5 \% \mathrm{CO}_{2}$ in air before fixation and processing for electron microscopy. Observations were made on changes in neutrophil and lymphocyte ultrastructure with special reference to lysosomal morphology; monocytes were not analysed, as it was not always possible to distinguish between auto- and heterophagosomes owing to their tendency to ingest cell debris. In 9 experiments the number of lymphocytes containing autophagosomes per 100 cells after incubation in $5-0.05 \mu \mathrm{g} / \mathrm{ml}$ chloroquine was recorded on 2 separate occasions, and the totals summed to give a final result of the number present in a 200-cell sample. Wilcoxon's matched pairs signed ranks test was applied to determine whether there was any significant difference between the number of autophagosomes present in lymphocytes after incubation in the various concentrations of chloroquine.

SEPARATION OF T AND B LYMPHOCYTES

$60 \mathrm{ml}$ blood from a healthy male volunteer was mixed with $1.5 \mathrm{ml}$ heparin, and the $\mathrm{T}$ and $\mathrm{B}$ lymphocytes were separated according to the method of Potter and Moore. ${ }^{4}$ The cell concentration was adjusted to $10^{7}$ per $\mathrm{ml}$ in DMEM, and $1 \mathrm{ml}$ aliquots of either T or $B$ cells were mixed with an equal volume of chloroquine solution to give a final concentration of 5 $\mu \mathrm{g} / \mathrm{ml}$. Medium-only controls were also prepared. Cells were incubated for 4 hours at $37^{\circ} \mathrm{C}$ in $5 \% \mathrm{CO}_{2}$ in air and then fixed and processed as above. Test and control grids were examined blind, the percentage of lymphocytes containing autophagosomes being recorded on 2 separate occasions and the results summed as before. This experiment was performed twice, and a chi-squared test was used to assess the presence of any difference between the 2 cell types.

ULTRAHISTOCHEMISTRY

In order to confirm the presence of lysosomes in lymphocytes cells were isolated as above and incu- bated with either 50 or $5 \mu \mathrm{g} / \mathrm{ml}$ chloroquine, or medium only, for 4 hours, after which they were suspension-fixed for exactly 6 minutes in prewarmed $1.25 \%$ glutaraldehyde in $0.05 \mathrm{M}$ cacodylate buffer $\mathrm{pH} 7 \cdot 4$ (final concentration). After 2 washes in $0 \cdot 1 \mathrm{M}$ cacodylate buffer they were left overnight and then stabilised in $0.2 \mathrm{M}$ ace tate buffer for one hour before incubation in the medium for aryl sulphatase activity ${ }^{5}$ for 2 hours at $37^{\circ} \mathrm{C}$. Cells were then rinsed briefly in acetate buffer before being washed in cacodylate buffer and processed as normal. Ultrathin sections were examined without further staining.

\section{Results}

\section{PHAG OCY TOS IS}

After 15 minutes' incubation in chloroquine only the highest concentration $(50 \mu \mathrm{g} / \mathrm{ml})$ showed a statistically significant degree of inhibition of particle uptake by neutrophils compared with controls $(p<0.01)$, with a mean phagocytic index of $30.5 \%$. By 90 minutes, however, exposure to both 50 and 5 $\mu \mathrm{g} / \mathrm{ml}$ resulted in a significant inhibition of phagocytosis in comparison with control preparations, with mean phagocytic indices of $39.4 \%$ and $26.5 \%$ respectively (Table 1 ). At $0.5 \mu \mathrm{g} / \mathrm{ml}$, although $33.5 \%$ inhibition was reached in one case, 2 were slightly stimulatory with phagocytic indices of $-2 \cdot 8 \%$ and $-0 \cdot 3 \%$, and the overall effect was not statistically significant in comparison with control cells (Table 1). In 7 of the 9 experiments the maximum degree of suppression was found at the highest concentration of chloroquine $(50 \mu \mathrm{g} / \mathrm{ml})$, but in 2 experiments concentrations of $5 \mu \mathrm{g} / \mathrm{ml}$ gave a marginally greater level of inhibition.

\section{MORPHOLOGICAL STUDIES}

After 1 hour's exposure to $50 \mu \mathrm{g} / \mathrm{ml}$ chloroquine, polymorphonuclear neutrophils showed slight swelling of some granules, with the formation of an electron-lucent rim or halo around the granule (Fig. 1). In some cases the normally electron-dense granule appeared to be showing signs of disruption, with a loosening of its structure to give a flocculent or fibrillar appearance; this was occasionally accompanied by a condensed core lying within the fibrillar matrix. There was more evidence of degranulation compared with control cells, and an occasional myeloid body was seen.

By 2 hours the swelling of neutrophil granules had become much more widespread, and after 4 hours' exposure to chloroquine the cells were filled with many vacuoles, their contents being in various stages of alteration (Fig. 2). Some contained electron-dense balls or flocculent material, while many granules had a loosely-woven texture similar to that found in occa- 
Table 1 Particle uptake by PMNs after 15 and 90 minutes in various concentrations of chloroquine $(0-50 \mu \mathrm{g} / \mathrm{ml})$

\begin{tabular}{|c|c|c|c|c|}
\hline & \multicolumn{4}{|c|}{ Chloroquine concentration $(\mu \mathrm{g} / \mathrm{ml})$} \\
\hline & 50 & 5 & $0 \cdot 5$ & Control \\
\hline \multicolumn{5}{|l|}{ No. particles in 100 cells $(15 \mathrm{~min})$} \\
\hline Mean $\pm \operatorname{SE}(n=8)$ & $230 \cdot 2 \pm 19 \cdot 6^{*}$ & $310 \cdot 2 \pm 35 \cdot 6$ & $308 \cdot 5 \pm 37 \cdot 0$ & $330 \cdot 9 \pm 36 \cdot 8$ \\
\hline Mean phagocytic index & $30 \cdot 5$ & $6 \cdot 0$ & $6 \cdot 6$ & \\
\hline \multicolumn{5}{|l|}{ No. particles in 100 cells $(90 \mathrm{~min})$} \\
\hline Mean $\pm \operatorname{SE}(n=9)$ & $248 \cdot 8 \pm 47 \cdot 1^{* *}$ & $302 \cdot 2 \pm 56 \cdot 7^{* *}$ & $376 \cdot 4 \pm 60 \cdot 0$ & $410 \cdot 6 \pm 52 \cdot 2$ \\
\hline Mean phagocytic index & $39 \cdot 4$ & $26 \cdot 5$ & $8 \cdot 5$ & \\
\hline
\end{tabular}

* $p<0 \cdot 01,{ }^{* *} p<0 \cdot 005$, by Wilcoxon's matched pair signed ranks test.

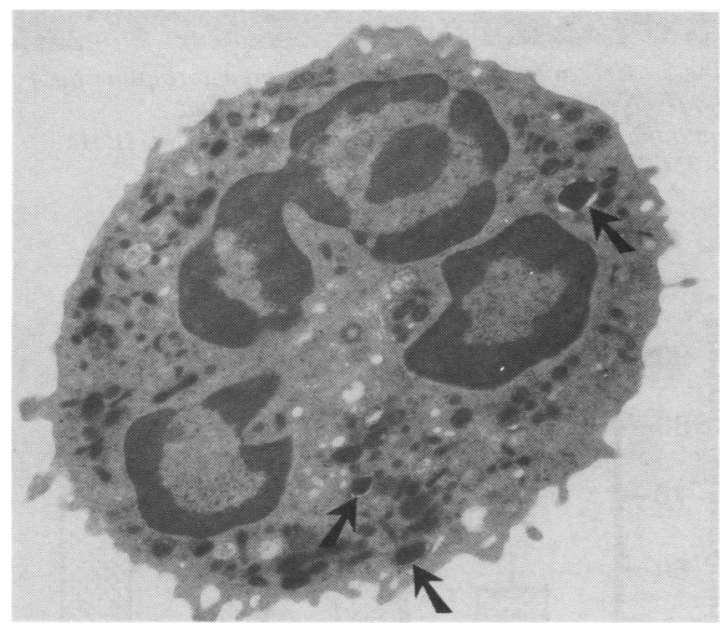

Fig. 1 Neutrophil after exposure to $50 \mu \mathrm{g} / \mathrm{ml}$ chloroquine for 1 hour. A halo can be seen around some granules (arrows). $(E M, \times 10125)$.

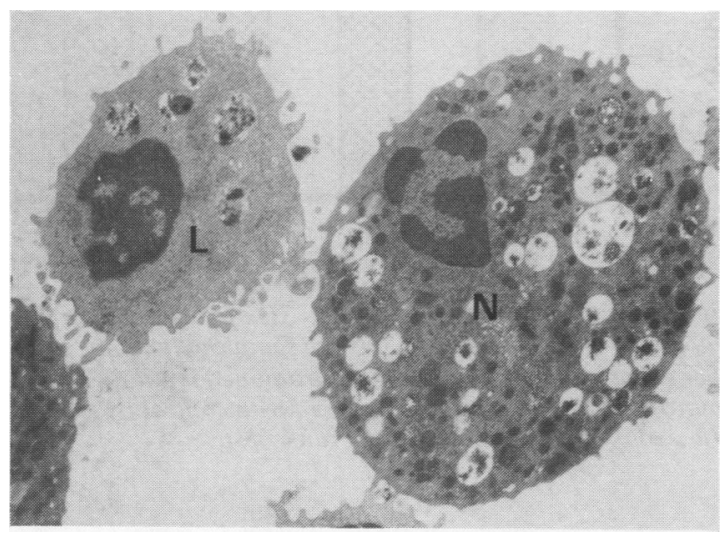

Fig. 2 A neutrophil (N) after incubation in $50 \mu \mathrm{g} / \mathrm{ml}$ chloroquine for 4 hours. The cell contains many large vacuoles and disintegrating granules. Within the lymphocyte (L) are 5 autophagosomes. $(E M, \times 6970)$. sional control cells. Several of the vacuoles were devoid of contents, which may have been outside the plane of the section. In contrast the control cells showed only a very occasional incidence of degranulation after 4 hours' incubation in the medium (Fig. 3 ). There was minimal swelling of Golgi vacuoles in some chloroquine-treated cases, but this did not reach significant proportions. Other organelles such as nuclei and mitochondria did not appear to differ from the controls at any stage of the incubation period.

The ultrastructure of lymphocytes showed a quantitative rather than a qualitative change during the 1to 4-hour incubation period with $50 \mu \mathrm{g} / \mathrm{ml}$ chloroquine, in that there was a gradual increase in the number of autophagosomes present (Fig. 2) compared with control cells. These vacuoles were filled with contents of variable electron-density, often containing one or more darkly staining inclusions. Lamellar structures with concentric membranous whorls and membranous invaginations indicative of early autophagosome formation were occasionally seen (Fig. 4). These vacuoles were present in the

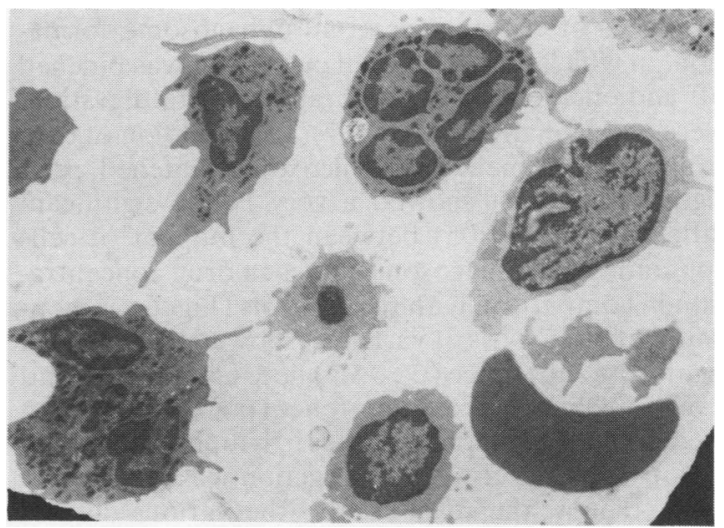

Fig. 3 Control cells after 4 hours' incubation in DMEM alone. $(E M, \times 3100)$. 


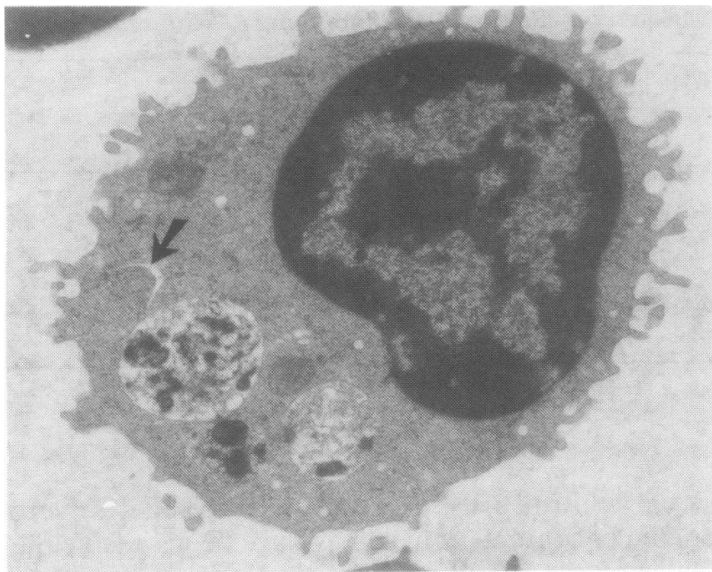

Fig. 4 A lymphocyte after incubation in $50 \mu \mathrm{g} / \mathrm{ml}$ chloroquine for 4 hours, containing large autophagosomes and a membranous invagination (arrow). (EM, $\times 10420)$.

control cells (see Fig. 6) but to a much lesser degree. They tended also to be smaller. Because this concentration of chloroquine appeared to be highly toxic and nonspecific in its action, no attempt was made to quantitate the number of autophagosomes found in the lymphocyte population.

After 4 hours' incubation in $5 \mu \mathrm{g} / \mathrm{ml}$ chloroquine there was no detectable difference in the ultrastructure of neutrophils in comparison with control cells. However, lymphocytes showed a significant increase $(p<0.005)$ in the number of cells containing autophagosomes compared with controls (Fig. 5). This feature was evident at concentrations as low as 0.05 $\mu \mathrm{g} / \mathrm{ml}$ chloroquine and appeared to be dose-related (Fig. 6). The vacuoles were slightly smaller than those found after exposure to $50 \mu \mathrm{g} / \mathrm{ml}$ but contained similar features such as electron-dense inclusions, lamellar structures, and flocculent material. Instances of early stages of autophagosome formation, in which part of the cell cytoplasm was pinched off and enclosed by a membrane prior to digestion, were occasionally seen (Fig. 7). Examination of data from 9 experiments by Wilcoxon's matched pairs signed ranks test showed a very highly significant difference $(p<0 \cdot 005)$ between the number of cells containing autophagosomes at each drug concentration in comparison with the controls (Fig. 6). A nonparametric analysis of variance ${ }^{6}$ showed there to be a significant difference $(p<0.05)$ between subjects and a very highly significant difference $(p<0.01)$ between the number of autophagosomes in lymphocytes at the various drug levels. The interaction was not significant-that is, the responses to the various chloroquine concentrations were similar for each blood sample tested.

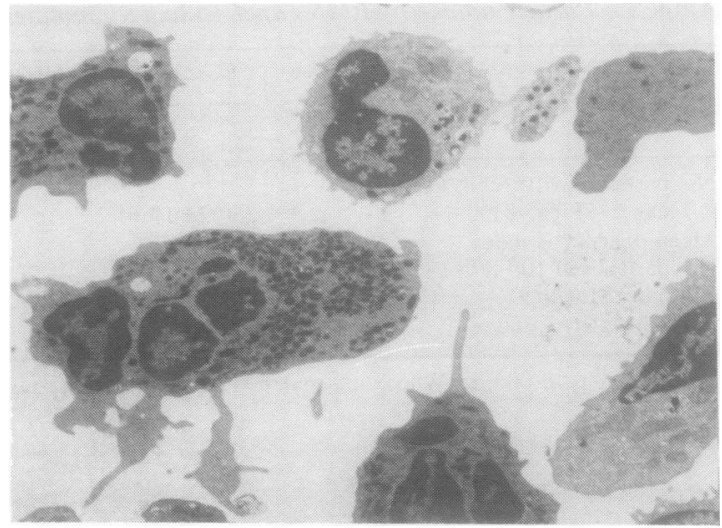

Fig 5 Cells after incubation in $5 \mu \mathrm{g} / \mathrm{ml}$ chloroquine for 4 hours. Neutrophils appear to be unaltered but autophagosomes can be seen in the lymphocytes. (EM, $\times 3500)$.

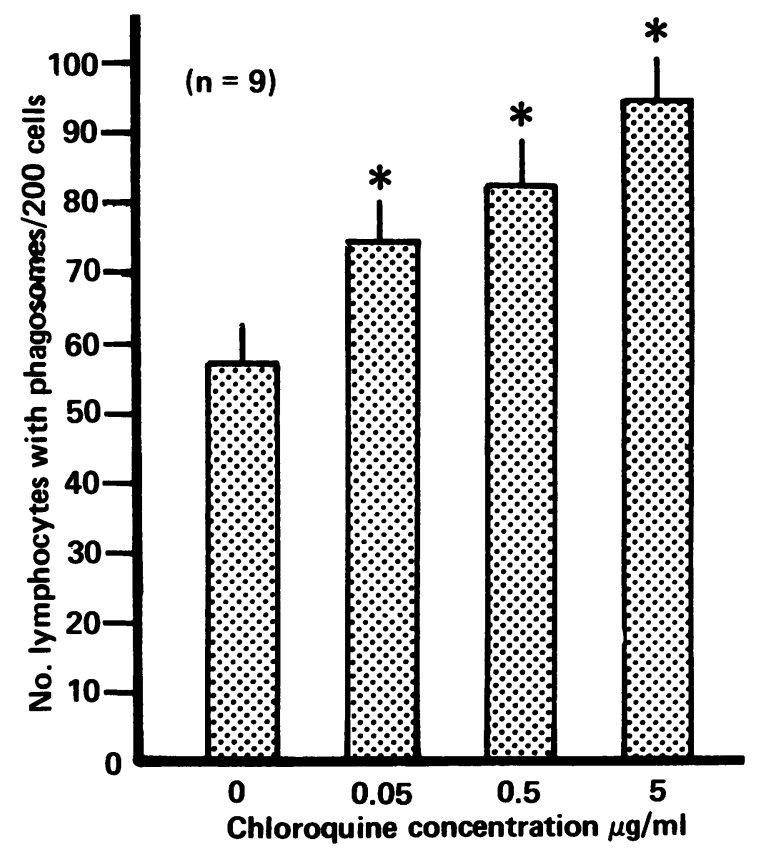

Fig. 6 Histogram showing mean $+S E$ of the number of autophagosomes present in a 200-cell sample oflymphocytes after exposure to 5-0.05 $\mu \mathrm{g} / \mathrm{ml}$ chloroquine for 4 hours and controls $(n=9)$. ${ }^{*} p<0.005$ compared with control by Wilcoxon's matched pairs signed ranks test.

\section{T AND B LYMPHOCYTE SEPARATION}

Statistical analysis by the chi-squared test showed there to be no significant difference between the susceptibility of $T$ and $B$ lymphocytes to the action of 


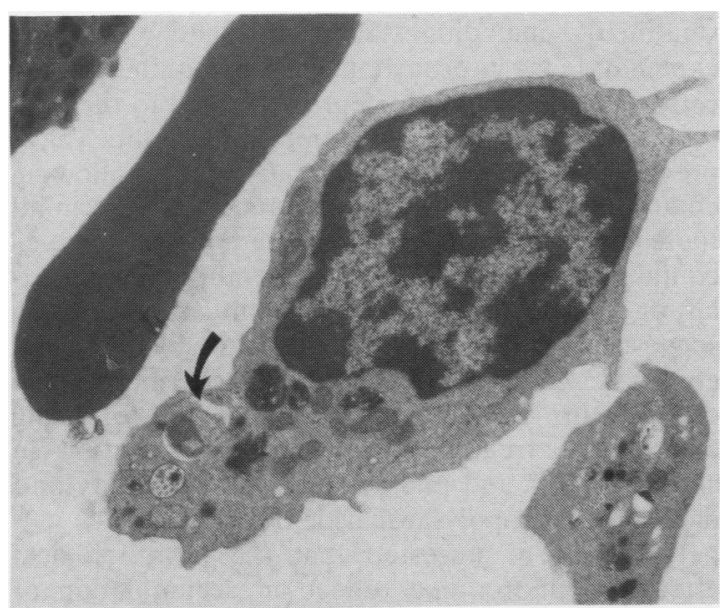

Fig. 7 Lymphocyte after incubation in $5 \mu \mathrm{g} / \mathrm{ml}$ chloroquine for 4 hours showing early autophagosome formation (arrow). (EM, ×9600).

$5 \mu \mathrm{g} / \mathrm{ml}$ chloroquine. Both populations showed a very highly significant increase $(p<0.001)$ in the number of autophagosomes present after chloroquine treatment compared with control groups (Table 2).

\section{U L T R A H IS T O CHEM IS TR Y}

Occasional aryl sulphatase-positive granules were found in lymphocytes from both test $(50$ and $5 \mu \mathrm{g} / \mathrm{ml}$ chloroquine) and control situations. Reaction product in the form of fine electron-dense deposits was also present in some autophagosomes, thus confirming the lysosomal nature of these inclusions (Fig. 8). Although no attempt was made to quantitate the amount of reaction product in each case, there appeared to be a decrease in enzyme activity in all cell types following incubation in chloroquine, which was more marked at the higher $(50 \mu \mathrm{g} / \mathrm{ml})$ concentration.

\section{Discussion}

Although the exact mode of action of chloroquine is unknown, it possesses both anti-inflammatory and

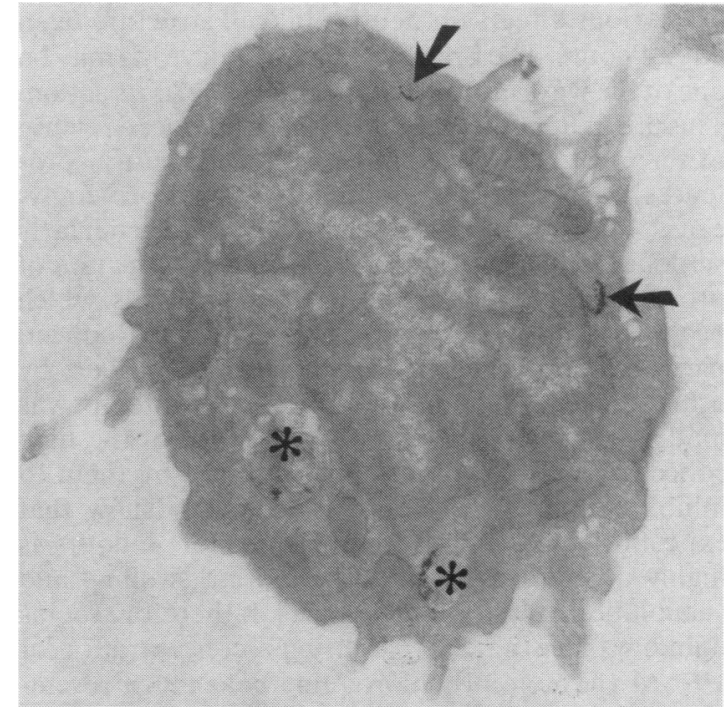

Fig. 8 Lymphocyte reacted for aryl sulphatase activity after exposure to $5 \mathrm{\mu g} / \mathrm{ml}$ chloroquine for 4 hours.

Electron-dense deposits can be seen in autophagosomes $\left({ }^{*}\right.$ ) and granules (arrows). (EM, $\times 20530)$.

immunosuppressive effects. Its many properties have been extensively reviewed ${ }^{278}$ and include lysosomal stabilisation, ${ }^{9}$ enzyme inhibition, ${ }^{10}{ }^{11}$ the suppression of chemotaxis ${ }^{12}$ and particle uptake by polymorphonuclear leucocytes ${ }^{12-14}$ and inhibition of DNA, RNA, and protein biosynthesis. ${ }^{15}$ It also influences immunological reactions by suppression of in-vitro transformation of lymphocyte $\mathrm{s}^{16}$ as well as reduction in cytotoxicity ${ }^{17}$ and the number of cells bearing immune associated surface markers. ${ }^{18}$

In this study we have demonstrated a significant dose-related increase in autophagosome production in lymphocytes after exposure to chloroquine, as well as an inhibition of particle uptake by polymorphonuclear leucocytes at concentrations approaching therapeutic plasma levels of the drug $(1.5 \mu \mathrm{M}$ or 0.8 $\mu \mathrm{g} / \mathrm{ml}) .{ }^{19}$ After 90 minutes all the specimens showed inhibition of phagocytosis at 50 and $5 \mu \mathrm{g} / \mathrm{ml}$ chloroquine, and 7 out of 9 were inhibited at $0.5 \mu \mathrm{g} / \mathrm{ml}$, with the 2 lower concentrations of the drug having no

Table 2 Autophagosome formation in separated $T$ and $B$ lymphocytes after 4 hours' incubation in $5 \mu g / m l$ chloroquine

\begin{tabular}{|c|c|c|c|c|c|c|c|c|}
\hline & $\begin{array}{l}T \text { cells } \\
+5 \mu \mathrm{g} / \mathrm{ml} \\
\text { chloroquine }\end{array}$ & $\begin{array}{l}T \text { cells } \\
\text { control }\end{array}$ & $\begin{array}{l}\text { Chi- } \\
\text { squared } \\
\text { value }\end{array}$ & $\begin{array}{l}\text { Significance } \\
\text { (p) }\end{array}$ & $\begin{array}{l}\text { B cells } \\
+5 \mu \mathrm{g} / \mathrm{ml} \\
\text { chloroquine }\end{array}$ & $\begin{array}{l}\text { B cells } \\
\text { control }\end{array}$ & $\begin{array}{l}\text { Chi- } \\
\text { squared } \\
\text { value }\end{array}$ & $\begin{array}{l}\text { Significance } \\
\text { (p) }\end{array}$ \\
\hline \multicolumn{9}{|l|}{ Autophagosomes } \\
\hline per 200 & Expt. 1 & 35 & $17 \cdot 4$ & $<0.001$ & 65 & 33 & $13 \cdot 0$ & $<0.001$ \\
\hline lymphocytes & Expt. 278 & 27 & $32 \cdot 3$ & $<0.001$ & 65 & 39 & $8 \cdot 1$ & $<0.005$ \\
\hline
\end{tabular}


deleterious effects on neutrophil cell structure even after 4 hours. The prevention of phagocytosis may be one of the ways in which chloroquine exerts its action. This might not only have the effect of reduced release of enzymes such as collagenase ${ }^{20}$ and neutral proteases capable of degrading cartilage proteoglycans ${ }^{21}$ to which joint tissues would be particularly susceptible, but may also decrease the production of prostaglandins, leucotrienes, and free radicals, which occur as a direct result of phagocytosis. ${ }^{22}$ Reduced particle uptake has previously been described by other workers, ${ }^{12-14}$ but in their studies no attempt was made to evaluate the effect on the cells of the high concentrations of chloroquine required by them to inhibit phagocytosis. Our results clearly show that exposure to $50 \mu \mathrm{g} / \mathrm{ml}$ chloroquine for 4 hours is highly deleterious to the cell, causing swelling and vacuolation of lysosomal granules. It therefore seems unlikely that studies ${ }^{1214}$ utilising a concentration of $10^{-3} \mathrm{M}(516 \mu \mathrm{g} / \mathrm{ml})$ chloroquine bear much resemblance to a biologically relevant situation. The importance of monitoring cells at the ultrastructural level cannot be too strongly emphasised, for moribund cells, although intact and not releasing lactate dehydrogenase, do not phagocytose, and it would be erroneous to attribute this to a specific action of the drug rather than to toxicity.

In a previous investigation ${ }^{3}$ we demonstrated a marked inhibition of phagocytosis by neutrophils after exposure to therapeutic concentrations of prednisolone which was associated with the biosynthesis of a protein or polypeptide, probably analogous to the protein isolated by Hirata et al. ${ }^{23}$ the production of which was also initiated in neutrophils by the action of glucocorticoids. This compound was found by them to inhibit phospholipase $A_{2}$ activity, an enzyme which cleaves arachidonic acid from membrane phospholipids. We suggested that phospholipase $A_{2}$ inhibition may depress phagocytosis by blocking the availability of membrane precursors necessary for the production of new plasma membrane required for the accommodation of ingested particles ${ }^{24}$ and it is interesting to note that chloroquine and its related compound mepacrine have both been shown to have a phospholipase-inhibiting action. ${ }^{11} 25$ As well as suppressing phagocytosis such an enzyme inhibition may account for the predominance of osmiophilic, membranous, electron-dense material seen in the autophagosomes of our own and other studies, which morphologically resembles undegraded phospholipid.

Autophagy is the process of sequestration of intracellular components and their subsequent degradation by lysosomes; it appears to be a normal physiological event, contributing to the turnover of cell constituents. ${ }^{26}$ It can be induced by a number of treatments, including starvation, ${ }^{27}$ and a possible explanation for its occurrence in chloroquine-treated cells may be amino-acid deprivation due to the malfunction of lysosomes. Lysosomal abnormalities have previously been described in many tissues following chloroquine therapy ${ }^{28}$ and a common feature in all these cases seems to be the appearance of vacuoles containing various amounts of membranous, lamellar, or particulate matter, the accumulation of which suggests incomplete or partial digestion by lysosomal enzymes. A number of workers have demonstrated changes in lysosomal enzyme activity following chloroquine treatment, including a reduction in cathepsin $\mathrm{B}_{1}{ }^{10}$ and phospholipase $\mathrm{A}_{2}{ }^{11}$ activity and decreased mucopolysaccharide degradation. ${ }^{29}$

It has been suggested that the morphological effects of chloroquine reflect an accumulation of autophagosomes due to the inhibition of breakdown rather than to a stimulation of autophagy. ${ }^{29}$ However, Read and $\mathrm{Bay}^{28}$ found evidence of an increase in the synthesis of lysosomes. Our study did not conclusively support either view but would suggest the former.

The particular susceptibility of lymphocytes to autophagosome formation may account for the immunosuppressive properties of chloroquine, perhaps by stabilising lysosomes, and thus preventing the intracellular release of enzymes such as RNA-ase necessary for the derepression and subsequent transformation of lymphocytes. ${ }^{1630-32}$ An alternative mechanism to explain immunosuppression by chloroquine relates to its effects on cell surface membranes, ${ }^{17}{ }^{18}$ within which structure it accumulates, ${ }^{33}$ leading to a failure of cell-to-cell recognition and receptor presentation and recycling. In fibroblasts the inhibition of receptor recycling is thought to result from, at least in part, the capacity of chloroquine to raise the intralysosomal $\mathrm{pH}^{34}{ }^{35} \mathrm{~A}$ similar mechanism may account for its antimalarial activity, the increase in Plasmodium lysosomal $\mathrm{pH}$ producing enzyme inhibition and a subsequent accumulation of undigested haemoglobin in giant vacuoles ${ }^{27}$ which resemble the autophagosomes found in mammalian tissues following chloroquine treatment. ${ }^{28}$

In this report we have demonstrated an effect on neutrophil and lymphocyte lysosomes after only a few hours in chloroquine. How these changes affect the long-term function and metabolism of the cell in rheumatoid arthritis is difficult to assess. Most workers agree that chloroquine takes a minimum of 4 weeks before maximal benefits are achieved. This apparent anomaly may be partly explained by an effect on precursor cells as well as circulating leucocytes, as previous studies have reported the presence of abnormal granules in myelocytes. ${ }^{36}$ All studies of the effects of chloroquine both in vivo and in vitro ${ }^{10}{ }^{37}$ 
indicate a common mode of action of the drug, leading to abnormalities of lysosomal activity which may, in rheumatoid disease, exert its effects by decreasing the amount of tissue damage caused by the action of proteases found in neutrophil granules. An inhibition of phagocytosis would also decrease enzyme release as well as cause a reduction in free radical generation and leucotriene and prostaglandin production, all of which would be beneficial in alleviating inflammation.

The hitherto undescribed increase in lymphocyte autophagosome production may also be of importance in conditions such as rheumatoid arthritis, where some populations of lymphocytes play an aggressive role, as this impedes their function and may be beneficial both by a direct effect and by allowing the restoration of normal immune responses.

It appears, therefore, that in the in-vitro situation chloroquine exerts a 2-pronged attack on leucocytes. Firstly, it has an inhibitory effect on phagocytosis, and secondly it increases autophagosome production in lymphocytes, which undoubtedly affects their function. In this respect the antirheumatic action of chloroquine parallels its anti-malarial activity. Studies are now in progress in our laboratory in which we are examining the circulating leucocytes from patients on chloroquine therapy to determine whether there is any change in the structure and frequency of lysosomes in the various cell types.

We thank Dr S. B. Lucas, Department of Medical Computation at Manchester University, for statistical assistance and advice, Dr M. Potter for performing the lymphocyte separations, and Dr A. J. Freemont for helpful discussion and criticism. The continued support of Dr Jones by the Dr Hadwen Trust for Humane Research is greatly appreciated.

\section{References}

1 Payne J F. A post-graduate lecture on lupus erythematosus. Clin J 1894; 4: 223-9.

2 Mackenzie A H, Scherbel A L. Chloroquine and hydroxychloroquine in rheumatological therapy. Clin Rheum Dis 1980; 6: 545-66.

3 Jones C J P, Morris K J, Jayson M I V. Prednisolone inhibits phagocytosis by polymorphonuclear leucocytes via steroid receptor mediated events. Ann Rheum Dis 1983; 42: 56-62.

4 Potter M R, Moore M. PHA stimulation of separated human lymphocyte populations. Clin Exp Immunol 1975; 21: 456-67.

5 Jones C J P, Fox H. An ultrastructural and ultrahistochemical study of the placenta of the diabetic woman. J Pathol 1976; 119: 91-9.

6 Scheirer C J, Ray W S, Hare N. The analysis of ranked data derived from completely randomized factorial designs. Biometrics 1976: 32: 429-34.

7 Zvaifler N J. Antimalarial treatment of rheumatoid arthritis. Med Clin North Am 1968; 52: 759-64.

8 Mackenzie H. An appraisal of chloroquine. Arthritis Rheum 1970; 13: 280-91.

9 Weissmann G. Labilisation and stabilisation of lysosomes. Fed Proc 1964; 23: 1038-44.
10 Wibo M, Poole B. Protein degradation in cultured cells. (2) The uptake of chloroquine by rat fibroblasts and the inhibition of cellular protein degradation and cathepsin $\mathrm{B}_{1} J \mathrm{~J}$ Cell Biol 1974; 63: 430-40.

11 Matsuzawa Y, Hostetler K Y. Inhibition of lysosomal phospholipase $A$ and phospholipase $C$ by chloroquine and 4,4' bis(diethylaminoethoxy) alpha, beta-diethyldiphenylethane J Biol Chem 1980; 255: 5190-4.

12 Ward P A. The chemosuppression of chemotaxis.J Exp Med 1966; 124: 209-25.

13 Chang Y H. Studies on phagocytosis. (2) Effect of nonsteroidal anti-inflammatory drugs on phagocytosis and on urate crystal-induced canine joint inflammation. $J$ Pharmacol Exp Ther 1972; 183: 235-44.

14 Smith R J. Modulation of phagocytosis by and lysosomal enzyme secretion from guineapig neutrophils: effect of nonsteroid anti-inflammatory agents and prostaglandins. $J$ Pharmacol Exp Ther 1977; 200: 647-57.

15 Ciak J, Hahn F E. Chloroquine: mode of action. Science 1966; 151: 347-9.

16 Trist D G, Weatherall M. Inhibition of lymphocyte transformation by mepacrine and chloroquine. J Pharm Pharmacol 1981; 35: 434-8.

17 Cameron D J, Churchill W H. Macrophage-mediated cytotoxicity in man: role of hydrocortisone, trypan blue, chloroquine and prednisolone. J Immunopharmacol 1981; 3: 77-85.

18 Nagarkatti P S, Nagarkatti M, Jain V C. In vivo and in vitro action of chloroquine on surface markers of human peripheral lymphocytes. Clin Exp Immunol 1980; 41: 166-72.

19 Wollheim F A, Hanson A, Laurell C B. Chloroquine treatment in rheumatoid arthritis. Correlation of clinical response to plasma protein changes and chloroquine levels. Scand $J$ Rheumatol 1978; 7: 171-6.

20 Lazarus G S, Daniels J R, Brown R S, Bladen H A, Fullmer H M. Degradation of collagen by a human granulocyte collagenolytic system. J Clin Invest 1968; 47: 2622-9.

21 Oronsky A L, Ignarro L J, Perper R J. Release of cartilage mucopolysaccharide-degrading neutral protease from human leukocytes. J Exp Med 1973; 138: 461-72.

22 Weissmann G. Activation of neutrophils and the lesions of rheumatoid arthritis. J Lab Clin Med 1982; 100: 322-33.

23 Hirata F, Schiffman E, Venkatasubramanian K-M, Solomon $D$, Axelrod J. A phospholipase $A_{2}$ inhibitory protein in rabbit neutrophils induced by glucocorticoids. Proc Natl Acad Sci USA 1980; 77: 2533-6.

24 Elsbach P. Lipid metabolism by phagocytes. Semin Hematol 1972; 9: 227-39.

25 Vallee E., Gougat J, Navarro J, Delahayes J F. Antiinflammatory and platelet anti-aggregant activity of phospholipase $A_{2}$ inhibitors. J Pharm Pharmacol 1979; 31: 588-92.

26 Glaumann H, Ericsson J L E, Marzella L. Mechanisms of intralysosomal degradation with special reference to autophagocytosis and heterophagocytosis of cell organelles. Int Rev Cytol 1981; 73: 149-82.

27 Homewood C A, Warhurst D C, Peters W, Baggaley V C. Lysosomes, $\mathrm{pH}$ and the antimalarial action of chloroquine. Nature 1972; 235: 50-2.

28 Read W K, Bay W W. Basic cellular lesion in chloroquine toxicity. Lab Invest 1971; 24: 264-9.

29 Lie S L, Schofield B. Inactivation of lysosomal function in normal cultured human fibroblasts by chloroquine. Biochem Pharmacol 1973; 22: 3109-14.

30 Allison A C, Mallucci L. Lysosomes in dividing cells, with special reference to lymphocytes. Lancet 1964 ; ii: 1371-2.

31 Hurvitz D, Hirschhorn K. Suppression of in vitro lymphocyte responses by chloroquine. $N$ Engl J Med 1965; 273: 23-6.

32 Gery I, Eidinger D. Selective and opposing effects of cytochalasin B and other drugs on lymphocyte responses to different doses of mitogens. Cell Immunol 1977; 30: 147-55. 


\section{Jones, Jayson}

33 Donato S D, Weismann U N, Herschokowitz N. Membrane adsorption and internalization of $\left({ }^{14} \mathrm{C}\right)$ chloroquine by cultured human fibroblasts. Biochem Pharmacol 1977; 26: 7-10.

34 Gonzalez-Noriega A, Grubb J H, Talkad V, Sly W S. Chloroquine inhibits lysosomal enzyme pinocytosis and enhances lysosomal enzyme secretion by impairing receptor recycling. $J$ Cell Biol 1980; 85: 839-52.

35 Sly W S, Fischer D, Gonzalez-Noriega A, Grubb J H, Natow-

icz M. Role of the 6-phosphomannosyl-enzyme receptor in intracellular transport and adsorptive pinocytosis of lysosomal enzymes. Methods Cell Biol 1981; 23: 191-214.

36 Fedorko M. Effect of chloroquine on morphology of cytoplasmic granules in maturing human leukocytes. An ultrastructural study. J Clin Invest 1967; 46: 1932-42.

37 Miller W S, Smith J G. Effect of acetylsalicylic acid on lysosomes. Proc Soc Exp Biol Med 1966; 122: 634-36. 